\title{
Wodziński na skraju hermeneutyki
}

DOI 10.35757/CIV.2016.19.13

W roku 1999 Józef Tischner opublikował w „Znaku” recenzję Światłocieni zła ${ }^{1}$ Cezarego Wodzińskiego. Nosiła ona tytuł Odwrót myślenia i pomimo wielu komplementów, jakimi Tischner obdarza samego Wodzińskiego oraz jego książkę, zawiera bardzo mocna krytykę. Patrząc $z$ perspektywy drogi, jaka pokonał Cezary Wodziński, zarzuty Tischnera wydaja się w pewien szczególny sposób celne. Mało tego, sądzę, że Wodziński nie próbował zarzutom tym zaprzeczyć, raczej traktował je jako aporię, która - skoro nie sposób jej obejść - trzeba drążyć.

Czego dotyczy ta krytyka? Najkrócej rzecz ujmujacc, dotyczy ona hermeneutyki i tego, w jaki sposób Wodzińskiego uprawianie hermeneutyki doprowadza ją do kresu. W szczegółach zaś wygląda tak.

Stary profesor pisze o profesorze in spe:

Erudycja Wodzińskiego budzi respekt. Respekt budzą również hermeneutyczne analizy tekstów poszczególnych autorów, od Platona, poprzez Kanta, po Lévinasa. Wodziński czuje się w świecie tekstów jak ryba w wodzie ${ }^{2}$.

Eukasz Kołoczek - doktor filozofii, badacz póżnej myśli Heideggera, zajmuje się także współczesnymi teoriami kultury. Pracuje w Instytucie Polonistyki i Kulturoznawstwa Uniwersytetu Szczecińskiego. Stypendysta OaAD na Uniwersytecie w Wiedniu. Członek Polskiego Towarzystwa Filozofii Religii. Dotychczas ukazały się dwie jego książki Bóg Heideggera. Ontologiczny wymiar „Przyczynków do filozofii” (Kraków 2013) oraz Być, czyli mieć. Próba transpozycji projektu „Przyczynków do filozofii” Martina Heideggera (Universitas, Kraków 2016).

1 C. Wodziński, Światłocienie zła, Leopoldinum, Wrocław 1998.

2 J. Tischner, Myślenie w odwrocie, „Znak” 1999, nr 6, s. 106-113. 
Powinno to poświadczać licencję hermeneuty. A jednak w Tischnerze budzą się wątpliwości:

$Z$ drugiej strony jednak jest coś niepokojącego w postawie, która cała „rzeczywistość” zła chce odnaleźć w... słowie o złu. Czyżby zło było tylko i wyłącznie „złym tekstem” o złu? ${ }^{3}$.

Problem tkwi w samym centrum hermeneutyki, jaka uprawia Wodziński:

Czy praca, która jest szczytowym osiagnięciem myślenia hermeneutycznego, nie jest również zapowiedzia jego granicy czy nawet klęski? Czy myślenie to nie gubi się w sobie? Czy konstrukcje, które zbudowało, by się określić, nie przysłaniaja mu świata?4${ }^{4}$.

Tischner jest fenomenologiem, co nie tylko oznacza sympatyzowanie $z$ pewna tradycja filozoficzna, ale także szczególne nastawienie filozoficzne. Wymaga ono, aby myślenie odnosiło się do czegoś. W przypadku filozoficznego badania zła konieczne jest odniesienie do samego zła. Według Tischnera zło jest dane. Oprócz wszystkich złych konsekwencji tego faktu, zwiazanych $z$ tym, że zła się doświadcza i sie je cierpi, ma to jedna szczęsna konsekwencję, mianowicie tę, że można zło myśleć. Myślenie i mówienie jest wtórne wobec zaistnienia zła. A mówić zasadnie o złu wolno tylko wtedy, gdy wpierw, przed wszelkim o nim mówieniem, zło uchwyci się jako fenomen. Tymczasem Wodziński jawnie kpi sobie $z$ tej rudymentarnej zasady. W jego hermeneutyce, wysublimowanej warsztatowo, brakuje tego, co $z$ zewnątrz hermeneutyki ja sama umożliwia i wprawia w ruch, co nadaje jej ostatecznie sens - brakuje mianowicie fenomenu. Hermeneutyka bez choćby minimalnego nawiazania do pozajęzykowej i pozatekstowej rzeczywistości wydaje się Tischnerowi jałowa. Być może kunsztowna, ale pusta.

Tutaj - powiada Tischner - myśl przestaje się zajmować „sprawa”, a zajmuje się soba [...]. Miałem jednak wrażenie, że prezentowana herme-

4 Ibidem. 
neutyka gubi coś istotnego. Oto sam Wodziński postawił mnie w środku Oświęcimia, a teraz zmusza do tego, bym badał strukturę tekstów, jakie filozofowie napisali o Oświęcimiu. Nie mam płakać nad losem ludzi, lecz nad losem „metafizyki”. Ktoś może powiedzieć, że jedno łączy się $\mathrm{z}$ drugim. Tak łączy się $\mathrm{w}$ tekście Lévinasa i Ricoeura, ale $\mathrm{w}$ tekście Wodzińskiego jakoś nie .

Ucieczka przed fenomenem, przed istota, a w tym konkretnym przypadku, „ucieczka myślenia przed problemem zła” pozbawia myślenie należytej powagi, wydaje się raczej, że jest ono dezercją. Myślenie zamienia się $\mathrm{w}$ odwrót myślenia. To wina hermeneutyki: „Wydaje mi się, że istotowe odkonkretnienie mowy nie jest przypadkiem. Jest losem hermeneutyki, która pozbyła się ciężaru fenomenologii"7. No i najcięższy chyba zarzut Tischnera: rozwadnianie zła samo jest postacia zła, a więc istnieje przynajmniej jedno miejsce, gdzie zasadnie można powiedzieć, że zło jest „złym tekstem” o złu - to właśnie Światłocienie zła:

Wodziński, który dokonuje (nie bez satysfakcji) „destrukcji” i „dekonstrukcji” dotychczasowej filozofii zła, stwarza wrażenie, że sam jest jakimś „przedłużeniem zła”, które postanowiło w nim i przez niego unieważnić dotychczasowa krytykę siebie ${ }^{8}$.

Zarzut Tischnera, który sprowadza się do zarzutu odfenomenologizowania hermeneutyki, można byłoby oczywiście odrzucić jako zbyt histerycznie trzymający się fenomenu zła. Zło nie musi mieć istoty, nie musi być dane jako substancja, wystarczy, że się tu lub tam, pod taka lub inna postacia zjawia. A skoro się zjawia i właśnie nie ma istoty, to każdy tekst o nim musi się jakoś rozłożyć, nie spiąć, nie scalić, bo właśnie tekst o złu, jakikolwiek tekst o fenomenie zła, o jego istocie, nie jest tekstem o złu, bo źle w zło trafia, bo mu uchybia. Wodziński deklaruje to niemal w pierwszych słowach swojej książki: „[...] zło prezentowało się myśleniu

5 Ibidem, s. 110.

6 Ibidem, s. 113.

7 Ibidem, s. 112 .

8 Ibidem, s. 110. 
każdorazowo tak przewrotnie i złośliwie, że odbierało to spójność i definitywność wszelkim definicjom [...]"9. A to oznacza, że zło, o którym tekst o złu traktuje, ale którego w tym tekście nie ma, umożliwia „destrukcję” i „dekonstrukcje” tekstu. Zło wcale nie pojawia się w tekście jako temat, jest raczej dziura w tekście, innym dla tekstu, czymś, co „robi” $z$ tekstem coś dziwnego, destruuje go lub dekonstruuje. To wystarczy, by „zły tekst” o złu stawał się tekstem dobrym, dobrym w tym sensie, że pozwalajacym owej negatywności zła wobec tekstu zjawić się w tekście jako negatywności właśnie ${ }^{10}$.

Zło być może jest właśnie takim tematem, który transponuje pisanie o nim w przeciwieństwo pisania o złu: wprawdzie tekst o złu ma za temat zło, ale zło jako temat nie jest „prawdziwym złem”. Dopiero „destrukcyjna” i „dekonstrukcyjna” lektura ujawnia w tekście o złu miejsce epifanii zła, lecz epifanii nie fenomenu zła, a raczej „pustego miejsca”, w którym fenomen ten nie może się zjawić. Dla praktyki hermeneutycznej oznaczałoby to, że nie sposób zła ująć, zrozumieć, wypowiedzieć (choć zarazem się go doświadcza), można jednak tworzyć dekonstrukcje tekstów na temat zła i ujawniać w ten sposób niemożliwość mówienia o złu. O złu mówić nie można, ale mówienie o złu umożliwia mówienie o niemożliwości mówienia.

Przed zarzutem Tischnera można byłoby również obronić cała filozofię Wodzińskiego, w której obserwujemy kurczowe trzymanie się konkretu. Owszem, ów konkret zawsze jest już konkretem widzianym poprzez tekst, a Wodziński nadbudowuje nad nim kolejne piętra znaczeń. Ale Wodziński nigdy nie opuszcza pola

\footnotetext{
9 C. Wodziński, Światłocienie zła, s. 6.

${ }^{10}$ Zob. ibidem, s. 7-8: „We wszystkich tych zmaganiach [które składają się na tę książkę - Ł.K.] [...] pokazuja się mniej lub bardziej wyraźnie, zwykle w sposób zamaskowany aniżeli wprost, ślady "zagubionego języka". Raz jeszcze podkreślmy: zaledwie ślady, albowiem system językowy o stabilnej i koherentnej strukturze leksykalno-semantyczno-gramantycznej nie jest ani dany, ani nawet zakładany. Trudno uchwytne pozostaja również wieloznaczne zwiazki i powikłania semantyczne między poszczególnymi udostępniającymi się "słowami". Odsłaniaja się pośrednio, nie-do-słownie już to w rozmaitych technikach ucudzysłowiania "zła", już to w nieusuwalnej aporetyczności myślenia próbującego się z tym, co najtrudniejsze”.
} 
wyznaczonego przez ów konkret. Zobrazuję to na przykładzie książki o spotkaniu Celana i Heideggera ${ }^{11}$. Spotkanie to jest konkretnym, historycznym zdarzeniem, czymś, co wydarzyło się w określonym czasie i w określonej przestrzeni. Znamy datę: 25 lipca 1967 roku i miejsce: chata Heideggera w Todtnaubergu. To jest konkret - punkt wyjścia książki. Jednak taki punkt wyjścia nie umieszcza dociekań Wodzińskiego na płaszczyźnie historii. Pierwszy gest, jaki wykonuje Wodziński, to uwieloznacznienie daty. Spotkanie ma datę podobnie jak Celanowski wiersz. A data wiersza to coś na wzór biblijnego „szibboletu”, słowa, które zdradza wymawiającego to słowo samym sposobem wymówienia $\mathrm{go}^{12}$. Data jest również zdrada, zdrada pojedynczości i niepowtarzalności wiersza, jest więc zdrada czasu (tego konkretnego „umiejscowienia” na osi czasu), wywinięciem się $z$ jego panowania, rozpostarciem kairosu $\mathrm{w}$ łonie upływającego chronosu ${ }^{13}$. Podobnie miejsce nie jest po prostu lokalizacja zdarzenia, ale miejscem szczególnym, warsztatem myślenia, przepojonym patosem, ojczyzna, jest miejscem zakorzenienia myśliciela ${ }^{14}$. Czas i miejsce spotkania natychmiast wprzegnięte zostaja przez Wodzińskiego $\mathrm{w}$ opowieść o spotkaniu, one są częścia tego spotkania, ponieważ nie są tylko „bytem w sobie” i „bytem dla” wszystkich komentatorów, ale przede wszystkim czymś uprzednio pomyślanym poetycko przez poetę i pomyślanym filozoficznie przez myśliciela. $Z$ każda strona książki opowieść o spotkaniu - czymś przecież prostym - komplikuje się niepomiernie, ponieważ na tym konkrecie nabudowane zostają kolejne piętra

\footnotetext{
${ }^{11}$ C. Wodziński, Kairos. Konferencja $w$ Todtnaubergu, Celan - Heidegger, Słowo/obraz Terytoria, Gdańsk 2010.

${ }^{12}$ Zob. J. Derrida, Szibbolet dla Paula Celana, przekład A. Dziadek, FA-art, Bytom 2000, s. 78.

${ }^{13}$ Ibidem, s. 43: „Data jest szalona - oto jest prawda. Co znaczy, że: nie jest nigdy tym, czym jest, tym, czym mówi, że jest, będąc zawsze mniej więcej tym, czym jest. Tym, czym jest, jest albo to, czym jest, albo to, czym nie jest. Nie zależy ona od istnienia, od jakiegoś sensu istnienia...”; por. C. Wodziński, Kairos..., s. 19: „20 stycznia“ [...] okazuje się równie nieznacząca, jak szibbolet, który jednak każdy z nas musi wymówić - musi wymawiać - by przypisać się dacie wpisanej w wiersz. Momentalność przemowy wierszy - nieskończonego przemawiania - ratuje i wspiera, na przekór potrzebie abstrakcji, nasze nieskończone pragnienie jedyności i pojedynczości, których innym imieniem jest przecież "czysta śmiertelność i daremność". Ocala w okamgnieniu".
}

${ }^{14}$ C. Wodziński, Kairos..., s. 20-27. 
znaczeń: sprawa wiersza i sąsiedztwa poezji i myślenia, Heideggera nazizm i Zagłada Żydów. To wszystko „gra” w spotkaniu, buduje rozmowę poety i myśliciela, choć o „rzeczywistym” przebiegu spotkania, to znaczy o tym, co powiedział Celan, a co Heidegger i czy w ogóle o czymś mówili, o tym niewiele wiadomo. Wiadomo natomiast, że obaj znajdowali się w "drodze do języka”, każdy na swój sposób, osobno jak „storczyk i storczyk”. Wodziński więc opisuje spotkanie, cały czas ten konkret, i wprawdzie w opis wikła cała poezję Celana i całą filozofię Heideggera, to jednak nie opuszcza przestrzeni wyznaczonej przez to spotkanie.

Wodziński trzyma się zatem cały czas „fenomenu”, tyle że ten „fenomen” nie istnieje poza tekstem: spotkanie Celana $z$ Heideggerem w tym sensie przekształciło się w legendę i tylko jako legenda stanowi dla Wodzińskiego „fenomen”. Legenda - historyczne zdarzenie, które staje się znaczące nie na mocy "danych historycznych”, lecz różnorodnych tekstów „kultury”. Podobnie sprawy się maja także w innych książkach Wodzińskiego. Takim „fenomenem legendarnym" jest nie tylko spotkanie filozofa i poety, o przebiegu którego wiadomo tylko $z$ wiersza napisanego przez poetę kilka dni po spotkaniu, ale także Odys, postać przecież nie historyczna, „przedmiot” rozważań literaturo- i językoznawców, religio- i mitoznawców. „Fenomenem legendarnym” jest jurodiwy, nieuchwytny dla fenomenologa w swoim tranzytywnym byciu. A oprócz zła destruującego tekst, „fenomenem” Wodzińskiego, być może nawet najważniejszym jego „fenomenem”, jest także rok 1933 w biografii Heideggera. W związku $z$ nim Wodziński określa swoją filozofię jako „bio-logię"15.

Umieszczam słowo „fenomen” w cudzysłowie, bo rzecz jasna nie jest on żadnym fenomenem w znaczeniu fenomenologicznym. Nie jest fenomenem nawet $\mathrm{w}$ znaczeniu, jakie nadał temu terminowi Heidegger w Byciu i czasie ${ }^{16}$. Zdaje się, że bardziej odpowiednim

\footnotetext{
${ }^{15}$ C. Wodziński, Metafizyka i metapolityka. Czarne zeszyty Heideggera, Słowo/obraz Terytoria, Gdańsk 2016, s. 226, 23 i n.

${ }^{16}$ Zob. M. Heidegger, Bycie i czas, przekład B. Baran, Wydawnictwo Naukowe PWN, Warszawa 1994 , par. 7 , s. 40-45.
} 
terminem byłaby tu „soczewka”. A może „pryzmat”17. Wodziński bowiem zawsze swoje hermeneutyczne badania ogniskuje w jakimś punkcie, w soczewce właśnie, w czymś, co bez wątpienia jest bytem pośród bytów, a zarazem jednak dzięki swej właściwości skupiania pozwala zobaczyć miejsce, w którym zbiega się wiele tworzacych światło wątków-promieni, aby następnie, dzięki soczewce, która przemienia się w pryzmat, wyodrębnić i uchwycić ową wielość. Dzięki temu - pozwolę sobie pociagnnąc jeszcze trochę tę metaforę - coś tak prostego jak światło ukazuje swoja złożoność $z$ ogromnej ilości barw. Sztuka hermeneutyczna Wodzińskiego pozwala poruszać mu się pomiędzy tymi wątkami-promieniami, budując dość przestronna przestrzeń tam, gdzie, wydawać by się mogło, nie ma już miejsca (gdzie wszystko wydaje się już wyjaśnione). Metafora światła i soczewki/pryzmatu ma tę ułomność, że pozostaje ona nieczuła na barwę, której Wodziński poświęcał najwięcej uwagi, mianowicie na czerń, kolor braku światła, warunek możliwości ukazania się czegokolwiek w świetle. „Fenomeny” bądź „konkrety” Wodzińskiego sa zatem takimi „miejscami”, które wprawdzie występuja pośród dobrze znanych nam miejsc i zdarzeń, zarazem jednak sa w szczególnym sensie niesamowite, ponieważ w mienieniu się złożonej wielości barw robią miejsce na „zjawianie się” braku światła, czerni.

Może zatem Tischner ma rację, że hermeneutyce Wodzińskiego brakuje fenomenu? Bo przecież ta metafora soczewki/pryzmatu nie oznacza nic innego, jak tylko to, że pisarstwo Wodzińskiego uwiedzione jest przez nicość, że o nic tu chodzi. „Fenomenem”, przed którym staje Wodziński i wokół którego uprawia hermeneutykę, jest miejsce zaznaczania się owego nic. Na swój sposób Tischner ma rację, formuła „nie ma fenomenu” ulega tylko

\footnotetext{
${ }_{17}$ Zob. C. Wodziński, Kairos..., s. 44: „[Spotkanie Celana z Heideggerem to - Ł.K.] Punkt w czasie i przestrzeni, który skupia i rozprasza wiele zawiąań sensu. Semantyczna tęcza - rozkładać ja na poszczególne wiazki świetlne to jakby próbować mamiace oczy, a przecież na wskroś naoczne złudzenie optyczne rozcinać krawieckimi nożycami. Czy nie lepiej wyobrazić sobie, jak tęcza łączy ze soba różne, często odległe krajobrazy? Jak ta punktualna, przypisana raz na zawsze do tego jedynego punktu data rozchodzi się w różne często odległe czasy i nawiązuje rozmowę $z$ wieloma innymi datami?”.
} 
transpozycji w formułe „fenomenem jest (miejsce dla) nic”. I czyż nie ma racji Tischner - i to nie tylko w odniesieniu do Światłocieni zła, ale proroczo, w odniesieniu do całej filozofii Wodzińskiego - twierdzac, że jest ona „odwrotem myślenia”? Czym innym przecież jest osuwanie się w nic, w nicość - jeśli nie nihilizmem? Utrata $z$ oczu fenomenu niechybnie prowadzić musi do „myśli zajmującej się samą soba”, krążenie wokół nicości skutkować może jedynie nicością myśli. Zatracił się Wodziński w swym kunszcie, oddał swe rzemiosło na zmarnowanie: zapisujac tyle stron, zapisał je na nic. Czy - parafrazując Tischnera - pisarstwo Wodzińskiego nie jest przedłużeniem nicości, pisaniem o nicości, które samo przepojone jest nicością? O jakżeby się Wodziński ucieszył na to przeformułowanie!

Tischner wykazuje się nie lada przenikliwością - i mówię to bez cienia ironii, choć oczywiście moim zamiarem jest pokazanie, jak Wodziński nie pozwala się w tę „pułapkę” uwikłać. Przenikliwość Tischnera polega na tym, że zauważa - już na podstawie Światłocieni zła - jak Wodziński wycofuje się z myślenia o tym, o czym traktuje język, i przemieszcza namysł w sam język. Tischner słusznie upatruje tu niebezpieczeństwa. Piszacy i czytajacy traca bowiem grunt pod nogami ${ }^{18}$, język i wypowiedzi wyślizguja się rozumieniu. Komunikacja staje się zagrożona. Czy wobec tego warto iść w tym kierunku?

Wodziński w pewnym miejscu zdaje sprawę ze swego rozstania $z$ hermeneutyka. Pretekstem do tego jest poezja Celana oraz kłopoty, w jakie wprawia ona Gadamera. Dla hermeneuty wiersze Celana sa nie lada wyzwaniem nie dlatego, że są przesiaknięte

\footnotetext{
${ }_{18}$ Tischner po przytoczeniu dłuższego cytatu ze Światłocieni zła rozkłada ręce: „Wyznam, że najzwyczajniej w świecie nie rozumiem. Nie twierdzę, że Wodziński nie widzi tego, o czym pisze. $Z$ pewnością ma taką właśnie intuicję układu sensów i znaczeń [...]. [tu następuje uwaga o Ricoeurze, któremu poświęcony był cytat poprzedzający tę wypowiedź; dalsza część odnosi się do tego, czego Tischner nie rozumie w wypowiedzi Wodzińskiego - Ł.K.:] Nie wiem, jakim argumentem "hermeneutycznym" przekonać "dekonstruktora" i "demistifikatora", że jego myślenie zostało w jakimś punkcie "oślepione" urokiem migotliwych znaczeń, więc zwyczajnie radzę raz jeszcze przemyśleć to, co "się" napisało", J. Tischner, Myślenie w odwrocie, s. 111.
} 
trudnymi do rozszyfrowania metaforami - Celan podobno twierdził, że nie ma w nich $\mathrm{w}$ ogóle metafor ${ }^{19}$, ale dlatego, że odmawiaja one prawa do interpretacji. Gadamer ma tu twardy orzech do zgryzienia - czytelnik powinien jednak wiersz jakoś zrozumieć, lecz wiersz broni się przed interpretacją. Komentarz nie może być zatem objaśnieniem tego, o co w wierszu chodzi, o czym wiersz jest. Istnieja co prawda komentarze, które nie przejmują się tym zakazem Celana, a instruktywnym przykładem jest tu praca Petera Szondiego, berlińskiego germanisty, który poświęcił obszerne studium jednemu $z$ wierszy, mianowicie Du liegst... z tomu Schneepart $^{20}$, w którym wykazal, że utwór ten "może stanowić drobiazgowo ikonograficzny zapis historycznego wydarzenie”, jakim był mord Karla Liebknechta i Róży Luksemburg w Berlinie w styczniu $1919 \mathrm{roku}^{21}$. Wiersz okazuje się wedle tej interpretacji szyfrem, problem polega jednak na tym, że złamanie tego szyfru wymaga nieprzeciętnej erudycji i zakrojonego na wielką skalę śledztwa, co w zasadzie uniemożliwia jego odczytanie (i zrozumienie - jeśli na złamaniu szyfru miałoby polegać zrozumienie wiersza) każdemu niemal czytelnikowi, wyłączając Petera Szondiego. Gadamer rezygnuje $z$ takiej interpretacji poezji Celana, ale nie rezygnuje $z$ jej zrozumienia. Komentarz jest zachęta, aby czytać - czytać tak długo, aż „zrozumienie przyjdzie samo”22. No właśnie, zrozumienie przyjdzie samo - ale czym ono jest, skoro nie chodzi tu o osadzenie tego, co wiersz mówi, w horyzoncie sensu, w którym porusza się czytelnik. Lektura wierszy Celana nakazuje zadać Gadamerowi raz jeszcze pytanie: „Ale co to w ogóle tu znaczy "rozumieć«?”23.

Formuła, za pomocą której Celan daje odpór wszelkim interpretacjom, brzmi: Wiersz przecież mówi. Zapisana została $\mathrm{w}$ mowie pod tytułem Meridian i w pełnym brzmieniu wygląda następująco: „Wiersz przecież mówi! Pozostaje pomny swych dat, ale - mówi.

\footnotetext{
${ }^{19}$ C. Wodziński, Kairos..., s. 37.

${ }^{20}$ Zob. H.G. Gademer, Czy poeci umilkną?, przekład M. Łukasiewicz, Homini, Bydgoszcz 1998.

${ }^{21}$ C. Wodziński, Kairos..., s. 35.

${ }^{22}$ H.G. Gadamer, Czy poeci umilkna?, s. 155.

${ }^{23}$ Ibidem, s. 135.
} 
Zapewne, mówi zawsze tylko w swojej własnej, najbardziej własnej sprawie"24. Wiersz mówi, to znaczy według Gadamera, że „wiersz wie lepiej niż autor”, że „tekst ma ostatecznie rację przeciwko poecie" ${ }^{25}$. Ale także przeciwko czytelnikowi! Stawką, o którą walczy Gadamer, jest sens. Czy wiersz, który przecież mówi, ma sens? Pytanie to jest o tyle dramatyczne, że Gadamer przyjmuje do wiadomości rozpad jednego uniwersalnego Sensu.

Wspólnota językowa, w której tradycyjne mity, podania, historia święta, pamięć historyczna tworzyły uniwersalny horyzont rozumienia, uległa rozbiciu. Żyjemy w świecie rozproszonych - to przekonanie dzieli Gadamer z Derrida - rozbieganych znaczeń, „semantycznych jednostek”, które nie jednocza się ze soba $[\ldots]^{26}$.

Zadaniem hermeneuty nie jest już wpisywanie wiersza w sensowny świat zachodniego człowieka, ale coś o wiele mniej: „desperacka obrona resztek sensu w świecie rozproszonych znaczeń, a nie poza nim" 27 . W świecie, w którym nie ma sensu, a tylko rozliczne, lokalne i jednostkowe sensy, zdarzaja się oczywiście interpretacje, które „dodaja” sens wierszowi z zewnątrz, „z góry”, a więc od czytelnika, który $z$ jakiegoś powodu chciałby, aby wiersz nie tylko mówił w sprawie, ale mówił w tej sprawie coś. Takimi właśnie interpretacjami sa według Wodzińskiego te wszystkie komentarze do wiersza Todtnauberg, które wskazuja, że Celan zawiódł się, oczekując od Heideggera tego jednego słowa, słowa „przepraszam”. „Trzeba wznieść się na bardzo wyniosły punkt widzenia - powiada

\footnotetext{
${ }^{24}$ P. Celan, Meridian, przekład C. Wodziński, „Przegląd Polityczny” 2009, nr 97/98, s. 162. ${ }^{25}$ H.G. Gadamer, Czy poeci umilkną?, s. 143. Zob. też s. 156: „W gruncie rzeczy całkowicie chyba zgadzam się $z$ poeta, że wszystko jest w tekście i że wszelkie czynniki biograficzno-okazjonalne zastrzeżone sa dla sfery prywatności. Ponieważ nie znajduja się w tekście, nie przynależą do niego. [...] Kto chce trafnie zrozumieć wiersz, musi w każdym razie odrzucić prywatne i okazjonalne elementy informacji. Tego w tekście nie ma. Cała rzecz w tym, by zrozumieć, co mówi sam tekst - niezależnie od wskazówek płynących $z$ informacji zewnętrznych".

${ }^{26}$ C. Wodziński, Kairos..., s. 41.

${ }^{27}$ Ibidem, s. 42, zob. H.G. Gadamer, Czy poeci umilkna?, s. 138: „Jest raczej tak, że wiersz, jako tocząca się rozmowa, wskazuje w kierunku jakiegoś nigdy niedającego się doścignąc sensu".
} 
Wodziński - by "sens spotkania" sprowadzać do tego "jednego słowa"”28, „wiersz Celana - powtórzmy - "nic o tym nie wie»"29. Interpretacje te pozostaja nietrafne, ponieważ dokładając owo "coś” do mówienia wiersza, pozostaja głuche na samo mówienie.

Czysta możliwość, która zapowiada i zaklina Celan: das Gedicht spricht ja. I nic! więcej. Oznaczałoby to jednak ni mniej, ni więcej, tylko definitywna abdykację interpretacji. Nie wbrew wydarzeniu sensu, lecz na jego rzecz. Ten najbardziej niewiarygodny i ryzykowny moment $\mathrm{w}$ życiu hermeneuty! ${ }^{30}$.

Po zrelacjonowaniu kłopotów hermeneuty, w jakie wprawia go wiersz, który wprawdzie mówi, ale nie mówi niczego konkretnego, i po wypowiedzeniu sugestii, że interpretacja może co najwyżej pozwalać wierszowi mówić, ale ostatecznie musi zniknaćc ${ }^{31}$, Wodziński składa deklarację. Jest to jeden $z$ nielicznych - jeśli w ogóle nie jedyny fragment $\mathrm{w}$ jego dziele (wyjmując książkę biograficzna Między doświadczeniem a anegdota), w którym Wodziński przemawia w pierwszej osobie liczby pojedynczej. Nie mówi o tekstach ani tekstami, ani w świetle tekstów, ale wypowiada swoja własna pozycję, jaka zajmuje wobec nich ${ }^{32}$.

Wytyczając Gadamerowskiej hermeneutyce drogę samozniesienia, sam na nią wkraczam i nie moge $z$ niej zboczyć. Jako że innej drogi niż interpretacja nie ma. Jestem hermeneutycznie upośledzony, i to tym bardziej, że

\footnotetext{
${ }^{28}$ C. Wodziński, Kairos..., s. 32.

${ }^{29}$ Ibidem, s. 33.

${ }^{30}$ Ibidem, s. 43.

${ }^{31}$ Zob. H.G. Gadamer, Czy poeci umilkną?, s. 138: „Trafna interpretacja wiersza w całości to interpretacja, która może zniknać bez śladu, gdy na nowo odtwarzamy wiersz - nie ma innego kryterium. Interpretacja, która jako taka wciąż jest obecna, gdy ponownie czytamy lub wypowiadamy wiersz, pozostaje czymś zewnętrznym i obcym. [...] Interpretację wiersza ocenia się według tego, czy pozwala przemówić samemu wierszowi”.

${ }^{32}$ Można byłoby poddać pod dyskusję kwestię, czy ta deklaracja odnosi się wyłącznie do pozycji, jaka zajmuje Wodziński w ramach tej książki, w której pada poniższa deklaracja, czy też można ekstrapolować ją na inne jego pisma. Pierwsza opcja sprawiałby, że Kairos jest najważniejszą książką Wodzińskiego, punktem szczytowym, w którym zdał on sobie sprawę ze szczególności swej filozofii. Druga natomiast domagałaby się potwierdzenia w innych miejscach tej opus, ale jej przyjęcie umożliwiałoby spojrzenie na dorobek Wodzińskiego $\mathrm{w}$ nowym świetle $-\mathrm{w}$ pewnym sensie zgodnie $\mathrm{z}$ intuicja Tischnera: filozofia Wodzińskiego jako filozofia skraju hermeneutyki.
} 
zdaję sobie sprawę $z$ nieuchronności samozniesienia. Śledząc rozproszony sens - liczba pojedyncza pragnęłaby ocalić coś, co już nie do ocalenia będę jednocześnie zacierał własne ślady. Moja praca interpretacyjna może być tylko pracowitym świadectwem zanikania interpretacji. Pogoni za niedościgłym? Nie inaczej - lecz z pełna przytomnościa, że owa pogoń za... nie ma określonego i trwale wytyczonego kierunku. Może oznaczać ruch wstecz, a nawet błądzenie po krawędzi nieznanej geometrom figury ${ }^{33}$.

Wodziński - upośledzony hermeneuta: nie może nim przestać być, choć wie już, że droga hermeneutyki prowadzi go do jej granic, a więc do miejsca, w którym konsekwentnie pomyślana hermeneutyka musi znieść sama siebie. Gdzie leży ta granica? Czy Tischner dobrze ją rozpoznał?

Instruktywna formuła jest tu owa Celanowska fraza: „wiersz przecież mówi”. Nacisk położony został na „akt” mówienia. To, co wiersz mówi, nie jest aż tak ważne - to znaczy jest ważne o tyle tylko, o ile pozwala wierszowi mówić. No właśnie: mówi wiersz - nie człowiek, nie do człowieka, nie o rzeczywistości, nie w jakimś kontekście (lecz: „w sprawie”). To znaczy: być może również to, ale syntagma „wiersz przecież mówi” nie zdaje sprawy z tego, co wiersz mówi, lecz $z$ tego, że mówi. Hermeneutyczne instrumentarium nie ma w swych zasobach narzędzi do wyjaśniania mówienia, choć wyśmienicie radzi sobie $z$ tym, co powiedziane. Kiedy jednak to, co powiedziane, staje się zaledwie pretekstem dla mowy, która wprawdzie to wypowiada, ale która przede wszystkim chce mówić i swoje mówienie wydobyć na plan pierwszy, to owo powiedziane musi zostać zniesione, choć przecież niezlikwidowane. To, co powiedziane, musi pozwolić mowie mówić (podobnie jak wszelka hermeneutyczna „obróbka” tego, co wypowiedziane). Oto ta niedająca się zamknąc $\mathrm{w}$ interpretację okoliczność fundamentalna: wiersz mówi. A pytanie „co mówi?”, paradoksalnie staje się niedorzeczne.

W filozofii Heideggera również dokonuje się przejście droga, która prowadzi do języka. A więc przejście od tego, co powiedziane,

${ }^{33}$ C. Wodziński, Kairos..., s. 45. 
do samego mówienia. Ma ono kolosalne konsekwencje. Otóż oznacza to, że nie tylko człowiek mówi językiem, lecz także sam język mówi. Więcej nawet, kryje się tu założenie, że człowiek nie jest już więcej podmiotem mówiącym. Wymaga ono oswojenia się $z$ paradoksalnymi na gruncie - nomen omen - logiki, syntagmami: „mowa mówi”, „mowa języka”. To doświadczenie mowy nie od strony człowieka, co przecież zawsze i wciąż oznacza: metafizycznie, lecz od strony samej mowy, a więc doświadczenie mowy na podstawie jej samej. Rugowanie metafizycznego modusu pociąga i tę konsekwencję, że mowa, która mówi, nie staje się podmiotem mówiącym, kimś na kształt i podobieństwo człowieka. Mowa, która mówi, nie mówi tak, jak mówi człowiek. Mowa, która mówi - istota mowy - ofiarowuje człowiekowi możliwość zamieszkania. Heidegger powie: „Mowa utrzymuje otwartym obszar, w którym człowiek zamieszkuje domostwo świata na ziemi pod niebem"34.

Wodziński prawdopodobnie przechodzi na niemą stronę języka wtedy, gdy woła: „Oddajmy głos milczącemu Nic. Stoimy "wbrew" niemu. Stoimy tym milczeniem"35. Bo milczenie ujmowane $z$ perspektywy mowy języka nie jest po prostu niewypowiadaniem słów, przerwą w mówieniu, ale samą istota mowy. Na czym polega to milczenie?

Wodziński, trzymając się swego „fenomenu”, czyli rozmowy, jaka prowadza Heidegger i Celan - powtórzę raz jeszcze: rozmowy, o której „rzeczywistym” przebiegu nie wiemy nic, ale o której wspomina wiersz Celana, o której traktuje jego poezja i filozofia Heideggera - otóż trzymając się tego „fenomenu”, Wodziński ustala, że zadaniem poety niemieckiego i niemieckiego myśliciela jest „strzec słowa w mowie”. To zadanie zostaje przez Heideggera umieszczone w dziejowym kontekście skończonej metafizyki, to jest fabrykacji zwłok ${ }^{36}$. Celan żywi przekonanie, że tej zagładzie podlega

\footnotetext{
${ }^{34}$ M. Heidegger, Aus der Erfahrung des Denkens 1910-1976, GA 13, Frankfurt am Main 1983, s. 150, cytat za C. Wodziński, Kairos..., s. 134.

${ }^{35}$ C. Wodziński, Kairos..., s. 224.

${ }^{36}$ „Rolnictwo jest teraz zmotoryzowanym przemysłem żywnościowym, tym samym w istocie, co fabrykacja zwłok w komorach gazowych i obozach zagłady, co blokady i skazywanie
} 
wszystko. Nic nie ocalało. $Z$ wyjątkiem języka. Język ocalał, choć nie uszedł bez szwanku. To oznacza dla Celana, że „problem” zagłady jest problemem językowym. Nie w tym naiwnym znaczeniu, że trzeba dobrać odpowiednie słowa, by wyrazić zagładę, wyrazić bowiem się jej nie da. Ale zarazem nie sposób o niej milczeć. Trzeba zdobyć się na takie mówienie, takie używanie i wykorzystywanie słów, aby skryta w nich mowa mowy, to jest milczenie mowy, to jest istota mowy, mogła odmawiać się człowiekowi. Słowo jest jedynym wehikułem istoty mowy. Bardzo niewygodnym, niebywale zdezelowanym, nienadającym się już do użytku. A jednak jedynym, jaki ocalał.

Wodziński w tak zarysowanej przestrzeni dostrzega bliskość Celana i Heideggera:

Rzeczywisty problem Celana ma naturę językowa. Tak jak i problem Heideggera. Poeta i myśliciel [...] „pisza”, każdy po swojemu, w języku. $\mathrm{W}$ tym samym języku. W tym paradygmatycznym przypadku jest to język niemiecki. Dla jednego i drugiego - jak powiadaja Niemcy Muttersprache ${ }^{37}$.

\footnotetext{
krajów na głód" (cytat z wykładu Heideggera pt. Das Ge-Stell, w: idem, Bremer und Freiburger Vorträge, GA 79, Frankfurt am Main 1994, s. 27, polski przekład za C. Wodziński, Kairos..., s. 189). Wodziński zdaje sprawę z głosów oburzenia tą wypowiedzią, która zrównuje krematoria $z$ polami rolnymi i produkcja żywności. Zarazem jednak precyzyjnie umieszcza ją w odpowiednim segmencie Heideggerowskiego myślenia - w kontekście „przemyślenia metafizyki jako techniki” (ibidem, s. 191). Techniczna wykładnia bycia oprócz tej niezbyt doskwierającej konsekwencji, że metafizyka znika jako subtelna dziedzina akademicka, a staje się tak bardzo bliska życiu, że czegokolwiek doświadczamy, cokolwiek robimy, zawsze doświadczamy i robimy metafizycznie, ma również konsekwencję inna, złowroga. Pod dyktando totalnej technizacji człowiek przemienia się w materiał ludzki, który nie tylko produkowany jest metodami in vitro, ale jest „fabrykowany także w komorach gazowych Auschwitz i eksploatowany na archipelagu Gułag" (ibidem, s. 193). Heidegger pozostaje bezwzględny w swej diagnozie: „Setki tysięcy umieraja en masse. Czy umierają? Zadaje im się śmierć. Sa zabijani. Stają się tylko ilościa, elementami zasobu, z którego fabrykuje się zwłoki. Czy umierają? Sa likwidowani w obozach zagłady" (cytat z M. Heidegger, Die Gefahr, w: idem, GA 79, s. 56, przekład za C. Wodziński, Kairos..., s. 193 i n). Zagłada Żydów umieszczona zostaje na planie dziejów Bycia i staje się wydarzeniem epoki dokonanej metafizyki, to znaczy bezwarunkowego nihilizmu. Jakkolwiek może gorszyć zestawienie produkcji żywności z produkowaniem zwłok, to jednak myśl w ten sposób wyrażona zbieżna jest $z$ Celana frazą: „Oświęcim nie ma końca". Nie skończyła się epoka, której Auschwitz jest emblematem.

${ }^{37}$ C. Wodziński, Kairos..., s. 206 i n.
} 
Podobnie dalej:

po swojemu milczy myśliciel Martin Heidegger. Inaczej milczy poeta Paul Celan. Wolno już teraz zaryzykować przypuszczenie, że obaj - choć różnie - milcza, jeśli wolno tak powiedzieć, w zbliżonym kierunku. Że obaj - choć $\mathrm{z}$ różnych punktów - zbliżaja się w jedno miejsce, które nie pozwala się ani nazwać, ani pojạc, ani wyobrazić inaczej niż w zmowie milczenia wiążącej ich obu ${ }^{38}$.

Obu pozostaje pielęgnacja słowa. Nie po to, by stało równo w szeregu wyznaczonym przez jakąś językową regułę. To raczej pielęgnacja słowa jako grobu (Celan: „słowa, no wiesz, takie zwłoki..."39), w którym nic (nie) żyje.

Otwarte pozostaje pytanie, jaka nazwą określić to, co w ten sposób zostaje ochronione. Czy jest to zło spoza dobra i zła? Czy raczej nic? Czy też za Heideggerem - Bycie? A może po Celanowsku Zagłada? A może boskość, $z$ która stale flirtuje jurodiwy? A może nieśmiertelność, na skraju której porusza się Odys? Nie sposób tego rozstrzygnąć, choćby dlatego, że każda nazwa będzie tu wskazywała na jakiś byt. Tymczasem nie chodzi tu o byt ani o to, co $\mathrm{w}$ mowie może zostać powiedziane. Właśnie w tym miejscu hermeneutyka dobiega kresu. Chodzi tu bowiem o to, by tak mówić, aby chronić miejsce dla czegoś całkiem innego, co nie jest przecież żadnym czymś.

Patrząc $z$ perspektywy późniejszych książek Cezarego Wodzińskiego, to przechodzenie ku mowie można dostrzec już w Światłocieniach zła:

Dlaczego język nie przylega „tu” [to jest w tradycyjnym mówieniu o złu - Ł.K.] do rzeczy równie żywo i naturalnie, jak skóra i ciało w posagach Myrona, Polikleta i Fidiasza? Czyżby natrafiał na przepaść milczenia? $\mathrm{W}$ równej mierze - przychylnego, wszak wyniosło ono język do rangi mowy, co nieprzychylnego - zakreślając jego granice, konfrontując nieustannie $z$ wroga mu niemowa. Przepaść myślenia, która gotowa jest pochłonąć wszystkie języki, wydalając je w nieznośnej dla myślenia

${ }^{38}$ Ibidem, s. 239.

${ }^{39}$ Ibidem, s. 225. 
metabolicznej polifonii „wieży Babel”, a zarazem zdolna tchnąc energię, energetyczne iskry, bez których język gaśnie w spopielałej definitywności uniwersalnego i homogenicznego esperanto ${ }^{40}$.

Józef Tischner miał $\mathrm{w}$ pewnym sensie rację $\mathrm{w}$ swojej recenzji ze Światłocieni zła. Wodziński doprowadza hermeneutykę na skraj. Odmawia temu, co powiedziane, prawa do czerpania swego sensu $\mathrm{z}$ odnoszenia się do pozajęzykowej rzeczywistości. Upatruje za to źródła owego sensu w ulotnej mowie samego języka. Sensem tego, co powiedziane, jest chronienie istoty języka (Bycia, zła, gościnności itd.). Wydaje mi się, że Wodziński jest niezwykle konsekwentny $\mathrm{w}$ tym dziele, które dla Tischnera mieści się już poza granica zrozumiałości i w sferze podwyższonego ryzyka. Ci, którzy nie lękaja się podejmować tego ryzyka i wykraczać poza granice ustanowione przez metody myślenia, będa podziwiali nie tylko kunszt Wodzińskiego w takim władaniu słowem, aby pokazywało ono to, co przez nie mówi, ale nade wszystko pomysłowość w wynajdywaniu miejsc i tekstów, owych „fenomenów”, w których można rozpoznać chronienie się tego, co przemawia przez słowo.

${ }^{40}$ C. Wodziński, Światłocienie..., s. 6 i n. 